\title{
The effect of country-of-origin image on purchase intention: The mediating role of brand image and brand evaluation
}

\author{
Nguyen Ngoc Hien ${ }^{a *}$, Nguyen Nguyen Phuonga, Tung Van Tran ${ }^{b}$ and Le Duc Thang
}

${ }^{a}$ Industrial University of Ho Chi Minh City, Ho Chi Minh City, Vietnam

${ }^{b}$ Ho Chi Minh City University of Technology (HUTECH), Ho Chi Minh City, Vietnam

C H R O N I C L E

Article history:

Received: October 26, 2019

Received in revised format: No-

vember 272019

Accepted: November 27, 2019

Available online:

November 27, 2019

Keywords:

Brand Evaluation

Brand Image

Country-of-Origin

Purchase Intention

\section{A B S T R A C T}

In today's competitive business environment, organizations are always seeking for valuable practices to build a strong brand and enhance purchase intention. Accordingly, this study is designed to propose and test the effect of country-of-origin image on brand image, brand evaluation and purchase intention. These relationships are verified through 283 customers with purchase intention of electric household appliances. Cronbach's alpha and confirmatory factor analysis (CFA) tests are applied to examine the reliability and validity of the scale. Structural Equation Modeling (SEM) is also adopted to test hypotheses. The finding shows that the country-of-origin image had a positive effect on brand image, brand evaluation and purchase intention. Brand image and brand evaluation also had a positive effect on purchase intentions. In addition, the study indicates that both brand image and brand evaluation played mediating roles on the relationships between country-of-origin image and purchase intention. As the result, some implications are discussed, and the next research direction is proposed.

(C) 2020 by the authors; licensee Growing Science, Canada

\section{Introduction}

The current globalization process leads to the participation of most of countries in the international commerce and marketing. The customer's acceptance toward a brand from a certain country plays a significant role to not only business but also the country. Scientists demonstrated that country-of-origin performs a crucial role in enterprises nowadays (Usunier, 2011; Kim et al., 2017). Structure of the country-of-origin has been widely studied for decades regarding various variables of international marketing, consumer behavior and branding. Jaffe and Nebenzahl (2006) considered the country-of-origin as the country where consumers are associated with a certain products or brands regardless the manufacture place. The impact of the countryof-origin refers to bias or influences of risk perception, product evaluation and purchase intention (Diamantopoulos, Schlegelmilch, \& Palihawadana, 2011). In developing countries, consumers prefer imported goods because of not only high quality but also their country-of-origin which affects their purchase decisions (Moradi \& Zarei, 2012). In addition, as brand is the basis for competing in the market, it should be identified, built up and managed carefully. Branding not only allows enterprises to gain competitive advantages to provide current products and services, but also helps businesses extend their brands to other products and services (Motameni \& Shahrokhi, 1998). Among factors affecting customer's awareness of brands, the country-of-origin is a significant one. Signals of country-of-origin help customers form beliefs and product evaluation affecting their purchase behavior (Mohd Yasin, Nasser Noor, \& Mohamad, 2007). In addition, Assael et al. (2007) argued that purchase intention is the final consequence of brand evaluation. In brief, although many studies on the effect of country-of-origin on consumer awareness of the brand, as well as the impact of brand on purchase intention were conducted, there were, as authors' understanding, very few researches exploring the relationship between image of country-of-origin, brand image, brand evaluation and purchase intention, especially the meditating role of brand image and brand evaluation.

* Corresponding author.

E-mail address: nguyenngochien.qn@iuh.edu.vn (N.N. Hien) 
Hence, The study focused on exploring: (1) the effect of country-of-origin on brand image and brand evaluation, (2) the effect of country-of-origin, brand image and brand evaluation on the purchase intention, and (3) the effect of mediating role of brand image and brand evaluation on the relationships of country-of-origin and purchase intention. This research was conducted in the electric household appliance sector in Vietnamese market (e.g. washing machine, refrigerator, air conditioner, etc.). The demand for electric household appliances is growing rapidly and becomes an opportunity for domestic and foreign brands. As 2017 statistics of the Ministry of Industry and Trade, consumer spending on electric household appliances was accounted for approximately $9 \%$ of personal consumer spending package, which was ranked at $4^{\text {th }}$ position in terms of consumer-spending scale in Vietnam. The industry's growth rate is forecasted to increase by over $10 \%$ per year in the next 5 years (in which the electric household appliance industry accounts for approximately 40\%), yet fierce competition from Japan, Korea, Germany brands is inevitable. Thus, this research not only offers theoretical contributions but also supports marketers to find ways to enhance competitiveness and boost customer's purchase intention in electric household appliances sector.

The rest of this paper is structured as follows: Related documents are reviewed, and hypotheses are developed, followed by research methods and data analysis results. Finally, conclusion including implications and future research directions are discussed.

\section{Literature review and hypotheses}

\subsection{Literature review}

\subsubsection{Country-of-origin}

Studying country-of-origin is the consideration of whether the country-of-origin (COI) of products affects consumers' appreciation and preferences or not. However, the country-of-origin image is applied in researches to clarify the specific aspects of the country affecting customers' perceptions and attitudes towards products of a certain country (Diamantopoulos, Schlegelmilch, \& Palihawadana, 2011). As Jaffe and Nebenzahl (2006), the COI is defined as the image of the country that consumers associate with a certain product or brand as its origin. Yet, the increasing dependence on global sourcing has made COI more complicated in which the image of the designing country, production, assembly, brand, etc. are included (Usunier, 2011). However, when consumers recognize that the product is of a particular brand, they tend to emphasize the country-ofbrand image (Hamzaoui-Essoussi, Merunka, \& Bartikowski, 2011). Therefore, it is not the country-of-origin image or country of assembly but the COBI impacting on the customers' attitude and buying behavior and competitiveness (Lim \& O'Cass, 2001). As mentioned in other previous studies, the country-of-origin image is defined as the country image, in which the brand is originated. The COI is the customer's combined perception on a particular country based on their previous awareness of its strength and weakness in production and marketing (Roth \& Romeo, 1992).

\subsubsection{Brand image}

Brand image has been considered as a significant concept in marketing since the 1950s. According to Keller (1993) and Kotler (1991) brand image was identified as awareness of a brand, reflected by brand associations and organized in consumers' minds. Keller (1993) argued that this association can be derived from the customers experience, information gathered, or the impact of consumers' available association. Brand image is an integral component of the brand knowledge when branding a product. In other words, the brand image prefers what consumers think about the brand, and the emotions that the brand arouses when thinking about it (Keller \& Lehmann, 2006). Hence, companies' competitive advantages in the market could be achieved based on a positive brand.

\subsubsection{Brand evaluation}

Consumers evaluate brands by using common attributes, various visible and invisible signs related to the brand as a product or as a person (Puzakova, Kwak, \& Rocereto, 2013). Brand evaluation is defined as the emotional response of consumers to a brand, such as excitement, trust and desire Sirianni et al. (2013). Lassar et al. (1995) divided brand assets into perceived quality and perceived value. The overall quality assessment is subjective and abstract. Therefore, perceived quality often does not match the actual product quality. This is the basis for comparing brands together, called brand evaluation. On the other hand, perceived value is the basis for buying a brand's product to distinguish it from competitors. The decision to buy certain brands comes from the value consumers feel and is the determining factor for a brand's success (Zeithaml, 1988).

\subsubsection{Purchase intention}

Purchase intention refers to the consumer's ability to plan or be willing to buy a certain product or service in the future (Chiu, Chang, Cheng, \& Fang, 2009). The purchase intention mainly constitutes a purchase behavior. Although Mittal and Kamakura (2001) argued that purchase intentions cannot be accurately predicted, the motivation pushes them toward a purchasing action. The intention can represent a person's motivation to carry out an activity (Conner \& Armitage, 1998). Determined intention is the driving force affecting behavior. Strong intentions lead to stronger behavior. The purchase intention reflects the prediction or plan of future behavior, or the probability of believing and turning into buying behavior. In addition, purchase intentions reflect consumers' intentions to purchase products or services based on their attitudes and emotions (Engel et al., 1995). 


\subsection{Hypotheses}

\subsubsection{The effect of country-of-origin image on brand image and brand evaluation}

The study of Hamzaoui-Essoussi et al. (2011) showed the macro image of country-of-origin positively affects the brand image. Diamantopoulos et al. (2011) also stated that the country-of-origin affects the brand image. It could be understood that when customers recognized the product belonging to a specific brand, they tend to emphasize the product's country-of-origin. For instance, although Nikes shoes are produced in many countries, they are also considered as an American product (HamzaouiEssoussi, Merunka, \& Bartikowski, 2011). Based on theoretical perspectives on the relationship between the COI and the brand image, the hypothesis was given as follows:

Hypothesis 1: The country-of-origin image has a positive effect on the brand image.

As Hui and Zhou (2003), if the manufacturing country is more disadvantageous than the country-of-origin, customers will evaluate the brand in a negative way. Jin et al. (2006) also stated that COI has even a more positive impact on customers' brand evaluation than manufacture country. Diamantopoulos et al. (2011) concluded that COI strongly affected the brand awareness and purchase intention. Hence, the hypothesis is stated as following:

Hypothesis 2: The country-of-origin image has a positive effect on the brand evaluation.

\subsubsection{The effect of country-of-origin image, Brand image, Brand evaluation on Purchase Intention}

Many customer behavior studies demonstrated that the COI was a significant factor influencing customers' purchasing decisions (Piron, 2002). Prendergast et al. (2010) emphasized the effect of COI on buying intention. The COI, hence, is one of the most crucial factors affecting evaluation of the foreign products (Kumara \& Canhua, 2010). Thus, the hypothesis was proposed as follow:

Hypothesis 3: The country-of-origin image has a positive effect on the customer's purchase intention.

According to Keller and Lehmann (2006), understanding the effect of brand image on customer purchases is one of the crucial questions in current brand management researches. Brand image is considered as an important sign in the purchase decisionmaking process, in which positive brand information affects the perceived quality, perceived value and customer's readiness for purchase (Dodds, Monroe, \& Grewal, 1991). Consumers are more likely to products with a positive brand image. As for Adenan et al. (2018), brand image influences customer buying decisions, so the hypothesis is given as follow:

Hypothesis 4: The brand image has a positive effect on customer's purchase intention.

Purchase intention is considered as a predictor of actual purchase behavior (Grewal, Monroe, \& Krishnan, 1998). Lee and Lim (2000) showed that both perceived quality and perceived value play an crucial role in influencing purchase intentions. Assael et al. (2007) determined that purchase intention is the final consequence of brand evaluation. Hence, the hypothesis is proposed below:

Hypothesis 5: Brand evaluation has a positive effect on customer's purchase intentions.

\subsubsection{The mediating role of brand image and brand evaluation}

Country-of-origin, brand image and brand evaluation are known for the effect on customers' perception of a product or brand (Hsieh, Pan, \& Setiono, 2004). Ko et al. (2009) demonstrated the relationship between country-of-origin image, brand image, perceived quality and purchase intention. The country-of-origin and brand image have positive effects on perceived quality, and perceived quality has a positive effect on purchase intention. In addition, the country-of-origin image will affect customer's product evaluation to form their attitude. Diamantopoulos et al. (2011) asserted that the country-of-origin image strongly influences brand awareness and purchase intention. Thus, based on previous researches, the country-of-origin image is determined to be the premise of brand image and brand evaluation. In addition, purchase intentions are considered final consequence. The hypothesis, hence, is given as follow:

Hypothesis 6: Brand image is the mediator in the process by which the country-of-origin image influences the customer's purchase intention.

Hypothesis 7: Brand evaluation is the mediator in the process by which the country-of-origin image influences the customer's purchase intention.

\section{Methodology}

In this study, as a large number of hypotheses need to be tested, the quantitative method is the appropriate one. The measurement scale is adopted from previous studies to design questionnaires and collect data through face-to-face interviews. The measurement scale and hypotheses of research model are then tested via SPSS 24.0 and AMOS 23.0 software.

\subsection{Measure}

All the items of the questionnaire (except for demographic and product types questions) are measured by a five-level likert scale (1="Extremely disagree" to 5="Extremely agree). Participants were asked to give their opinions on some questions (presented in Table 1) related to their selected brand. All scales of concepts in the research model are adopted from previous 
researches. As scale proposed by Yasin et al., (2007), the scale the country-of-origin image consists of 7 variables. The brand image scale of Ansary and Hashim (2017) with 6 items, five-items scale of brand evaluation proposed by Spears and Singh (2004), and five-items scale of purchase intention suggested by Bian and Forsythe (2012) are applied in this research.

\subsection{Sample and data collection}

The data were collected via structured questionnaires distributed to the customers in Ho Chi Minh city and Da Nang city with the convenience sampling method. The respondents were asked to choose their concerned electric household appliances (e.g. washing machine, refrigerator, air-conditioner, etc.) with one specific brand for the chosen product categories. The participants were asked to answer the questionnaire based on the selected brand. The last session of the questionnaire was used to collect the demographic information (gender, age, income, and qualification). The pilot research was conducted for pre-testing the questionnaire with a small sample $(n=30)$ including experts in the field of electrical appliance and customers as well. Participants were asked to express their opinions on the overall structure and the clarity of the questionnaire. The results showed that most of the participants agreed with the questionnaire. However, based on the feedback, the ambiguous question (like "I feel this brand comfortable") was modified. (Details shown in Table 1).

Hair (2010) recommended that the sample size could be determined as five respondents per item to be analyzed (5:1 ratio). Accordingly, among 352 questionnaires collected, 283 questionnaires can be used for further analysis. There are 116 male respondents (41\%) and 167 females (59\%). As classified by age, the age of under 20, from 21 to 30, from 31 to 40, and 41 and above respectively are accounted for $11 \%, 62 \%, 15 \%$ and $12 \%$, respectively. Regarding monthly income, it was divided into groups of under VND 5 million with 54 respondents (19\%), from VND 5 million to VND 10 million with 71 respondents (25\%), from VND 10 million to VND15 million with 116 respondents (41\%), and more than VND15 million with 42 correspondents (15\%). In terms of qualification, there are 59 participants $(21 \%)$ of high school or lower qualification, 116 participants $(41 \%)$ of secondary high school to bachelor, and $48(17 \%)$ of postgraduate.

\section{Research findings}

\subsection{Measurement Scale testing}

Affirmative Factor Analysis (CFA) was adopted for the entire structure to adjust the measurement scale and evaluate the validity of measurement structures. 03 items with low factor loading (less than 0.5) were omitted (Details shown in Table 1).

Table 1

Factor weights of the measurement scale

\begin{tabular}{|c|c|}
\hline Variables & Weight \\
\hline \multicolumn{2}{|l|}{ Country-of-origin Image $(\alpha=0.912, \mathrm{CR}=0.91, \mathrm{AVE}=0.63)$} \\
\hline COI1. This country is creative in production & 0.29 \\
\hline COI2. The country's technology is high & 0.83 \\
\hline COI3. The country's designs are beautiful & 0.88 \\
\hline COI4. This country's professional skills are creative & 0.72 \\
\hline COI5. This country has highly qualified worker & 0.69 \\
\hline COI6. This is a prestigious country & 0.85 \\
\hline COI7. This is an advanced country & 0.79 \\
\hline \multicolumn{2}{|l|}{ Brand Image $(\alpha=0.89, \mathrm{CR}=0.89, \mathrm{AVE}=0.62)$} \\
\hline BI1. This brand's quality is high & 0.78 \\
\hline BI2. This brand's features are better than its competitors's ones & 0.72 \\
\hline BI3. This brand's characteristics can be distinguished from competitors & 0.89 \\
\hline BI4. This brand does not disappoint its customers & 0.84 \\
\hline BI5. It is one of the best brands in the industry & 0.71 \\
\hline BI6. This brand is stable in the market & 0.32 \\
\hline \multicolumn{2}{|l|}{ Brand evaluation $(\alpha=0.75, \mathrm{CR}=0.79, \mathrm{AVE}=0.50)$} \\
\hline BE1. I find this brand interesting & 0.91 \\
\hline BE2. I find this brand good & 0.71 \\
\hline BE3. I find this brand useful & 0.58 \\
\hline BE4. I find this brand promising & 0.28 \\
\hline BE5. Im attracted to this brand & 0.66 \\
\hline \multicolumn{2}{|l|}{ Purchase Intention $(\alpha=0.88, \mathrm{CR}=0.89, \mathrm{AVE}=0.61)$} \\
\hline PI1. I will purchase this brand's product immediately & 0.74 \\
\hline PI2. I will purchase this brand's product in the near future & 0.82 \\
\hline PI3. I would like to own this brand's product & 0.79 \\
\hline PI4. I'm confident of purchasing this brand's product regardless of time & 0.77 \\
\hline PI5. I will introduce this brand's product to my friends & 0.77 \\
\hline
\end{tabular}

$\alpha$ : Cronbach's alpha, CR: Composite Reliability, AVE: Average Variance Extracted

Source: Author's data analysis result

The results indicate that the degree of freedom is 551, and this model is suitable for market data $($ Chi-square/df $=2.38<3$; $\mathrm{CFI}=0.962>0.9 ; \mathrm{GFI}=0.945>0.9 ; \mathrm{TLI}=0.96>0.9$ and $\mathrm{RMSEA}=0.047<0.08)$. Because the measurement scales of brand image, brand evaluation, intention to purchase have no correlation between measurement errors, the observed variables are unidirectional, and scale of country-of-origin image is not unidirectional. The standardized weights of the observed variables fluctuate from 0.58 to 0.91 which are accepted (greater than 0.5 ), and the unstandardized weights are statistically significant ( $\mathrm{p}=0.00$ ) with reliability of $95 \%$. Hence, the observed variables used to measure concepts achieve required level of convergent values. 
As correlation coefficients of different pair concepts compared to 1 are statistically significant, the components achieve the distinguished values. The result of testing reliability and variance extract of the concepts show that the Cronbach's alpha reliability and Composite Reliability of the components are greater than 0.6 , and the variance extract is greater than 0.5 . Therefore, all measurement scales ensure high reliability (Hair, 2010).

\subsection{Estimating structural relationships}

\subsubsection{Result of SEM analysis of the theorical model}

The results of structural model testing (Fig. 1) demonstrate the model's degrees of freedom is 418, with p-value $=0.00<0.05$. The indicators are consistent with market data (Chi-square/df $<3$; CFI, GFI, TLI $>0.9$, RMSEA $<0.08$ ).

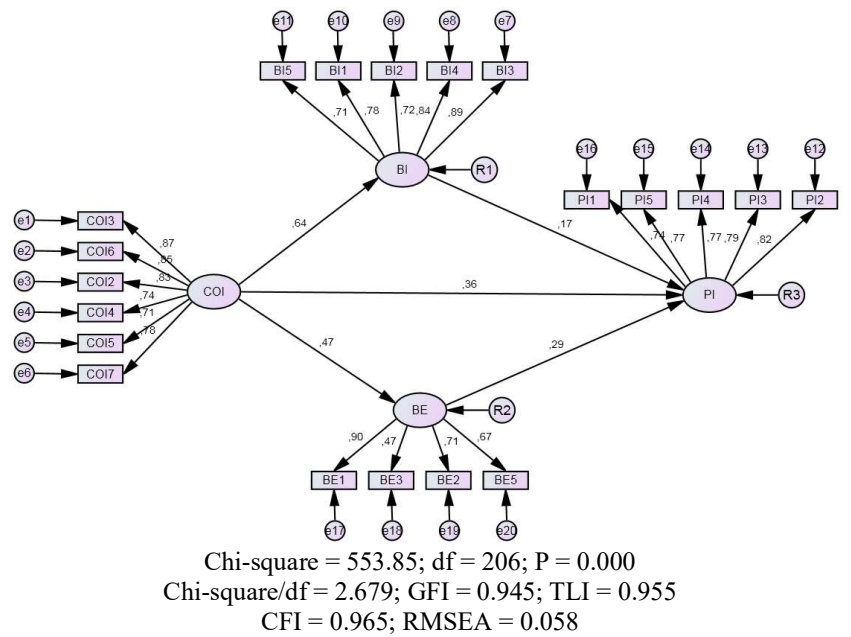

Fig. 1. Results of SEM analysis of theoretical models (standardized)

Source: Author's data analysis result

The results of estimating the main parameters of the model (Table 2) show that the relationships in the model are statistically significant because of the value of $\mathrm{p}<0.05$. Thus, hypotheses $\mathrm{H} 1, \mathrm{H} 2, \mathrm{H} 3, \mathrm{H} 4, \mathrm{H} 5$ are accepted.

Table 2

Regression coefficients of relationships in the theoretical model

\begin{tabular}{|c|c|c|c|c|c|c|}
\hline Hypotheses & Relationships & $\begin{array}{l}\text { Unstandardized } \\
\text { coefficients }\end{array}$ & $\begin{array}{c}\text { Standardized } \\
\text { coefficient }\end{array}$ & $\begin{array}{c}\text { Standard } \\
\text { errors }\end{array}$ & $\begin{array}{c}\text { Critical } \\
\text { value }\end{array}$ & P-value \\
\hline H1 & Country-of-origin image $\rightarrow$ Brand image & 0.796 & 0.648 & 0.072 & 11.033 & 0.000 \\
\hline $\mathrm{H} 2$ & Country-of-origin image $\rightarrow$ Brand evaluation & 0.420 & 0.459 & 0.058 & 7.264 & 0.000 \\
\hline H3 & Country-of-origin image $\rightarrow$ Purchase intention & 0.344 & 0.374 & 0.075 & 4.596 & 0.031 \\
\hline H4 & Brand image $\rightarrow$ Purchase intention & 0.118 & 0.158 & 0.055 & 2.159 & 0.000 \\
\hline $\mathrm{H} 5$ & Brand evaluation $\rightarrow$ Purchase intention & 0.293 & 0.292 & 0.065 & 4.530 & 0.000 \\
\hline
\end{tabular}

\subsubsection{Testing mediating hypothesis}

To determine the significance of mediating roles, four conditions are required to satisfy: (1) The country-of-origin image has a significant effect on mediating variables (brand image and brand evaluation; (2) Brand image and brand evaluation have significant effects on purchase intention; (3) the country-of-origin image has a significant effect on the purchase intention, and (4) the effect of country-of-origin image on purchase intention is not statistically significant or declining when calculating the effect of mediator Andrews te al., (2004).

Table 3

Results of model testing

\begin{tabular}{|c|c|c|c|c|c|c|c|c|}
\hline Model & $\chi^{2}$ & df & $\chi^{2} / \mathbf{d f}$ & $\mathbf{P}$ & GFI & TLI & CFI & RMSEA \\
\hline Model 1 & 246.7 & 87 & 2.84 & 0.00 & 0.965 & 0.943 & 0.975 & 0.038 \\
\hline Model 2 & 88.99 & 42 & 2.12 & 0.00 & 0.948 & 0.968 & 0.976 & 0.063 \\
\hline Model 3 & 222.25 & 100 & 2.22 & 0.00 & 0.945 & 0.911 & 0.926 & 0.075 \\
\hline Model 4 & 256.06 & 86 & 2.98 & 0.00 & 0.908 & 0.916 & 0.931 & 0.064 \\
\hline \multicolumn{3}{|c|}{ Relationships } & \multicolumn{2}{|c|}{ Model 1} & \multicolumn{2}{|c|}{ Model 2} & Model 3 & Model 4 \\
\hline \multicolumn{3}{|c|}{ Country-of-origin image $\rightarrow$ Brand image } & \multicolumn{2}{|c|}{$0.663 * * *$} & & $0.649 * * *$ & \\
\hline \multicolumn{3}{|c|}{ Country-of-origin image $\rightarrow$ Brand evaluation } & \multicolumn{2}{|c|}{$0.484 * * *$} & & & & $0.461 * * *$ \\
\hline \multicolumn{3}{|c|}{ Brand image $\rightarrow$ Purchase intention } & \multicolumn{2}{|c|}{$0.376^{* * *}$} & \multicolumn{4}{|c|}{$0.148 * *$} \\
\hline \multicolumn{3}{|c|}{ Brand evaluation $\rightarrow$ Purchase intention } & \multicolumn{2}{|c|}{$0.426 * * *$} & & & & $0.288 * * *$ \\
\hline \multicolumn{5}{|c|}{ Country-of-origin image $\rightarrow$ Purchase intention } & \multicolumn{2}{|c|}{$0.611 * * *$} & $0.515 * * *$ & $0.479 * * *$ \\
\hline
\end{tabular}


Two conditions (1) and (2) are tested by model 1 (Table 3). The estimated results demonstrate that the model is consistent with market data, and the relationships are statistically significant with the significance level of 0.01 . Hence, the conditions (1) and (2) are satisfied. Condition (3) is tested in model 2, and the results are proved to be consistent with market data. The relationships between the country-of-origin image and the purchase intention is statistically significant with the significance level of 0.01, which means the condition (3) is met. Finally, the condition (4) is verified by comparing model 3 and model 4 with model 2.The results show the effect of the country-of-origin image on the purchase intention decreases from 0.611 to 0.515 when calculating the effect of mediator of brand image, and drops from 0.611 to 0.479 when calculating the brand evaluation mediator. Therefore, brand image and brand evaluation are partly mediator in the effect of the country-of-origin image on the customer's purchase intention. As the results, hypotheses $\mathrm{H} 6$ and $\mathrm{H} 7$ are accepted.

\section{Discussion of research findings and implications}

\subsection{Discussion of research findings}

This study aims to examine the effect of country-of-origin image on brand image, brand evaluation and customer's purchase intentions in the electrical home appliance industry. The research's measurement scale was adopted from previous studies. The result of testing measurement scales shows that the scales of country-of-origin image, brand image, brand evaluation and purchase intention were unidimensional scales and statistically significant in the electrical home appliance industry in Vietnamese market. For the relationships between concepts, the research demonstrates a significant positive relationship between the country-of-origin image and the brand image. As the research result of Yasin et al. (2007), the country-of-origin image plays a primary role in creating brand image. The country-of-origin of brands is perceived by consumers as the country with advanced, prestigious, and creative design. Accordingly, the country-of-origin is considered an external link of brands, customers will, therefore, develop favorable or unfavorable links to brand images originating from that country. The study also shows the effect of the country-of-origin image on customer's brand evaluation. Based on the country-of-origin image, customers assess the quality and value of electric household appliances based. When buying new products, consumers tend to feel uncertain (Wu \& Wang, 2011). Thus, finding information about the product is carried out to ensure a proper decision. The country-of-origin is considered as a significant information to evaluate the brand of the product.

The research results also prove that the country-of-origin image impacts on the customer's purchase intention, which implies that the country-of-origin plays an indispensable role in the of process of making purchase decisions. Customers also develop their beliefs and perceptions of a brand based on the country-of-origin. The results reflect consumer's belief in brands originating from developed countries (e.g. The United States, Japan, Korea). As the result, they are more popular and often selected during the purchase decision process. In addition, the results also confirm the crucial role of brand image and brand evaluation in customers' purchase. Good image and highly-evaluated brands will create a stronger purchase intention. The research results confirm the previous research conclusions of Assael (2007) and Adenan et al. (2018).

Finally, brand image and brand evaluation are partly mediator of the relationship between the country-of-origin image and the purchase intention. According to Frazier et al., (2004), the mediator will clarify how or why a factor influences its output. Hence, it can be explained that when the brand comes from a well-evaluated country, the image of the brand will be better and the customers will evaluate the brand higher, and eventually create a stronger purchase intention. This result is consistent with ones of Diamantopoulos et al. (2011) that the country-of-origin image strongly affects brand awareness and purchase intention.

\subsubsection{Implications}

This study provides business's managers with some important practical implications. Firstly, the study shows the significant role of the country-of-origin image in the electrical home appliance industry in Vietnam. In today's business world, customers feel difficult to choose a product because too much information of products of the same category is provided by businesses. Therefore, consumers use the information of the country-of-origin image as a crucial information to evaluate the product. The results of this study show that the country-of-origin image affects both brand image, brand evaluation and purchase intention of customers for electric household appliances. The country-of-origin image is considered as a country with advanced, prestigious, and creative professional skills, which is an important external link for electric household appliances.

Customers will develop perceptions and favorable or unfavorable attitudes towards the brand based on the brand's countryof-origin and thereby affects their purchase intention. Hence, the electrical appliance bands will gain advantages if they originate from a country which is highly appreciated by customers, and vice versa. As a consequence, businesses should have a reasonable strategy to manage customer awareness about the country-of-origin. For businesses with favorable country-oforigin, businesses should consider the country-of-origin as an important sign in advertising programs to increase customers' awareness and purchase intentions. On the contrary, if an enterprise originating from the underestimated country, the enterprise should have a strategy to focus on other product's features such as product quality and service, shape, price, etc. to enhance competitiveness.

Secondly, research also identifies the importance of brand image and brand evaluation. In the sector of electric household appliance with fierce competition, companies are required to seek for ways to remain competitive in the market. One way to achieve this goal is to create a positive brand image in customer's minds, as well as enhance positive brand awareness from 
customers. The results of this study determine that brand image and brand evaluation both directly affect the purchase intention, and also play an indirect role in the relationship between the country-of-origin image and the purchase intention. Thus, electric household appliance brands should devote their efforts to maintain and improve their brand image in customer's minds. Well-managed brand links include quality improvement, logos and experiences that will create a favorable brand image. In addition, customers will have a higher purchase intention to the highly-appreciated brands with a better attitude. Thus, managers should pay attention to establish a brand associated with customer attitudes. Improving customer evaluation of the brand has a positive impact on the purchase intention.

\subsubsection{Limitations and future research directions}

As many other studies, this study also has contained some shortcomings. In terms of the nature of the research sample, the research's data were collected through non-probability sampling technique in two major cities leading to the restricted collecting data areas. A larger and more representative research help researchers to generalize the research findings. Secondly, respondents were asked to choose a brand and answer questions related to their favorite chosen brand. Although this choice is common when brand relationships are studied, this may lead to reports of stronger relationships between respondents and selected brands. Therefore, the results may invalid in case of the weaker relationships between respondents and brands. Further researches can solve this problem by assigning a particular brand for customers to evaluate. Finally, this study focuses only on the electric household appliance industry. However, this problem may be different in other industries. Therefore, this study needs to be conducted in various industries to get a better insight

\section{References}

Adenan, M. A., Ali, J. K., \& Rahman, D. H. A. A. (2018). Country of origin, brand image and high involvement product towards customer purchase intention: empirical evidence of east malaysian consumer. Jurnal Manajemen dan Kewirausahaan, 20(1), 63-72.

Andrews, J., Netemeyer, R., Burton, S., Moberg, D., \& Christiansen, A. (2004). Understanding adolescent intentions to smoke: An examination of relationships among social influence, prior trial behavior, and antitobacco campaign advertising. Journal of Marketing, 68(3), 110-123.

Ansary, A., \& Hashim, N. M. H. N. (2018). Brand image and equity: The mediating role of brand equity drivers and moderating effects of product type and word of mouth. Review of Managerial Science, 12(4), 969-1002.

Assael, H., Pope, N., Brennan, L., \& Voges, K. (2007). Consumer Behaviour (1st Asia-Pacific Edition). Brisbane: John Wiley and Sons.

Bian, Q., \& Forsythe, S. (2012). Purchase intention for luxury brands: A cross cultural comparison. Journal of Business Research, 65(10), 1443-1451.

Chiu, C., Chang, C., Cheng, H., \& Fang, Y. (2009). Determinants of customer repurchase intention in online shopping. Online Information Review, 33(4), 761-784.

Conner, M., \& Armitage, C. (1998). Extending the theory of planned behavior. Journal of Applied Social Psycholigy, 28(15), 1429-1464.

Diamantopoulos, A., Schlegelmilch, B., \& Palihawadana, D. (2011). The relationship between country-of-origin image and brand image as drivers of purchase intentions: a test of alternative perspectives. International Marketing Review, 28(5), 508-524.

Dodds, W. B., Monroe, K. B., \& Grewal, D. (1991). Effects of price, brand, and store information on buyers' product evaluations. Journal of Marketing Research, 28(3), 307-319.

Engel, J. F., Blackwell, R. D., \& Miniard, P. W. (1995). Consumer behavior, $8^{\text {th }}$ eds., Tokyo: The Dryden Press.

Frazier, P., Tix, A., \& Barron, K. (2004). Testing moderator and mediator effects in counseling psychology research. Journal of counseling psychology, 51(1), 115.

Grewal, D., Monroe, K. B., \& Krishnan, R. (1998). The effects of price-comparison advertising on buyers' perceptions of acquisition value, transaction value, and behavioral intentions. Journal of Marketing, 62(2), 46-59.

Hair, J. F. (2010). Multivariate data analysis. Pearson College Division.

Hamzaoui-Essoussi, L., Merunka, D., \& Bartikowski, B. (2011). Brand origin and country of manufacture influences on brand equity and the moderating role of brand typicality. Journal of Business Research, 64(9), 973-978.

Hsieh, M. H., Pan, S. L., \& Setiono, R. (2004). Product-, corporate-, and country-image dimensions and purchase behavior: A multicountry analysis. Journal of the Academy of Marketing Science, 32(3), 251-270.

Hui, M. K., \& Zhou, L. (2003). Country-of-manufacture effects for known brands. European Journal of Marketing, 37(1/2), 133-153.

Jaffe, E. D., \& Nebenzahl, I. D. (2006). National images and competitive advantage: The theory and practice of place branding. Copenhagen: Copenhagen Business School Press.

Jin, Z., Chansarkar, B., \& Kondap, N. M. (2006). Brand origin in an emerging market: perceptions of Indian consumers. Asia Pacific Journal of Marketing and Logistics, 18(4), 283-302.

Keller, K. L. (1993). Conceptualizing, measuring, and managing customer-based brand equity. Journal of Marketing, 57(1), $1-22$.

Keller, K. L., \& Lehmann, D. R. (2006). Brands and branding: Research findings and future priorities. Marketing science, 25(6), 740-759. 
Kim, N., Chun, E., \& Ko, E. (2017). Country of origin effects on brand image, brand evaluation, and purchase intention: A closer look at Seoul, New York, and Paris fashion collection. International Marketing Review, 34(2), $254-271$.

Ko, E., Kim, K. H., Kim, S. H., Li, G., Zou, P., \& Zhang, H. (2009). The relationship among country of origin, brand equity and brand loyalty: comparison among USA, China and Korea. Journal of Global Academy of Marketing Science, 19(1), 47-58.

Kotler, P. (1991). Marketing management: Analysis, planning, implementation, and control. Seventh Edition. English: Prentice-Hall.

Kumara, P., \& Canhua, K. (2010). Perceptions of country of origin: An approach to identifying expectations of foreign products. Journal of Brand Management, 17(5), 343-353.

Lassar, W., Mittal, B., \& Sharma, A. (1995). Measuring customer-based brand equity. Journal of Consumer Marketing, 12(4), 11-19.

Lee, H. S., \& Lim, S. J. (2000). The effect of price and brand on the perceived quality, value and purchase of clothing. Journal of the Korean Society of Clothing and Textiles, 24(4), 498-509.

Lim, K., \& O'Cass, A. (2001). Consumer brand classifications: an assessment of culture-of-origin versus country-of-origin. Journal of Product \& Brand Management, 10(2), 120-136.

Mittal, V., \& Kamakura, W. (2001). Satisfaction, repurchase behavior: Investigating the moderating effect of customer characteristics. Journal of Marketing Research, 38(1), 131-142.

Mohd Yasin, N., Nasser Noor, M., \& Mohamad, O. (2007). Does image of country-of-origin matter to brand equity? Journal of Product \& Brand Management, 16(1), 38-48.

Moradi, H., \& Zarei, A. (2012). Creating consumer-based brand equity for young Iranian consumers via country of origin sub-components effects. Asia Pacific Journal of Marketing and Logistics, 24(3), 394-413.

Motameni, R., \& Shahrokhi, M. (1998). Brand equity valuation: a global perspective. Journal of Product \& Brand Management, 7(4), 275-290.

Piron, F. (2002). International outshopping and ethnocentrism. European Journal of Marketing, 36(1/2), 189-210.

Prendergast, G., Tsang, A., \& Chan, C. (2010). The interactive influence of country of origin of brand and product involvement on purchase intention. Journal of Consumer Marketing, 27(2), 180-188.

Puzakova, M., Kwak, H., \& Rocereto, J. F. (2013). When humanizing brands goes wrong: The detrimental effect of brand anthropomorphization amid product wrongdoings. Journal of Marketing, 77(3), 81-100.

Roth, M., \& Romeo, J. (1992). Matching product category and country image perceptions: A framework for managing country-of-origin effects. Journal of International Business Studies, 23(3), 477-497.

Sirianni, N., Bitner, M., Brown, S., \& Mandel, N. (2013). Branded service encounters: Strategically aligning employee behavior with the brand positioning. Journal of Marketing, 77(6), 108-123.

Spears, N., \& Singh, S. N. (2004). Measuring attitude toward the brand and purchase intentions. Journal of Current Issues \& Research in Advertising, 26(2), 53-66.

Usunier, J. (2011). The shift from manufacturing to brand origin: suggestions for improving COO relevance. International Marketing Review, 28(5), 480-496.

Wu, P. C., \& Wang, Y. C. (2011). The influences of electronic word-of-mouth message appeal and message source credibility on brand attitude. Asia Pacific Journal of Marketing and Logistics, 23(4), 448-472.

Zeithaml, V. A. (1988). Consumer perceptions of price, quality, and value: a means-end model and synthesis of evidence. Journal of Marketing, 52(3), 2-22.

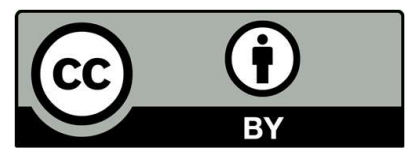

(C) 2020 by the authors; licensee Growing Science, Canada. This is an open access article distributed under the terms and conditions of the Creative Commons Attribution (CC-BY) license (http://creativecommons.org/licenses/by/4.0/). 